\title{
21308 一対のヒトによる協調バランス運動から受ける感性 Kansei Evaluation in Coupled Human Balancing Tasks
}

$\bigcirc$ 正 日下田 淳 (群馬高専)
正 吉田 勝俊 (宇都宮大院)

\author{
橋元 啓人（群馬高専）
}

Atsushi HIGETA, Gunma National College of Technology, 580 Toribamachi, Maebashi-shi, Gunma Hiroto HASHIMOTO, Gunma National College of Technology, 580 Toribamachi, Maebashi-shi, Gunma Katsutoshi YOSHIDA, Graduate School of Engineering, Utsunomiya University, 7-1-2 Yoto, Utsunomiya-shi, Tochigi

\begin{abstract}
In this paper, we investigate the relationship between sense and manipulation in coupled human balancing tasks. For this purpose, we propose a measurement system to obtain the balancing error product by two human subjects stabilizing a coupled inverted pendulum model in cooperation. After the experiment, each subject evaluates the performance of manipulation of both his own self and the partner. The result shows that the correlation analysis on sense and motion of the subjects implies that some correlations can be found between the balancing error and the sense.
\end{abstract}

Key Words: Human Manipulation, Cooperative Motion, Sensory Analysis, Movement Strategy

\section{1. はじめに}

著者らは，相手が明らかな状況下で2名のヒトが協調して創発す る協調バランス運動において, 感性工学的な手法の導入により，ヒ トの協調バランス運動における操作とそこから受ける感性との関 係を一部明らかにしてきた(1).

本報では, 相手が明らかでない状況下において, ヒトの協調バラ ンス運動と感性との関連を明らかにする.

\section{2. 協調ハランス荃動の測定システム}

\section{1 ヒトか蝶作可能な結合侄立振子モデル}

本報で用いるモデルは, Fig.1に示す $A_{i}$ を台車， $B_{i}$ を振子とする2 台の等価な倒立振子 $\mathrm{A}_{i} \mathrm{~B}_{i}(i=1,2)$ の先端を剛体リンク $\mathrm{B}_{1} \mathrm{~B}_{2}$ で連 結した4質点からなる，結合倒立振子モデルである.

ヒトによる結合倒立振子モデルへの入力を実現するため, 各台車 の制御入力 $u_{i}$ を,

$$
u_{i}=-K\left(x_{i}-x_{h i}\right)-L \dot{x}_{i}
$$

とおく.ここで， $x_{h i}$ は各台車の目標位置であり，ヒトの操作によ り入力される. これにより，ヒトが結合倒立振子モデルを操作する ことが可能となる.

\section{2 湨定システムの櫵成}

協調バランス運動測定システムの概要をFig.2に示す. 測定システ ムは，結合倒立振子モデルの数值シミュレータ，マウス2台，スク リーンから構成されており,スクリーンには結合倒立振子モデルの 力学アニメーションが表示される. 被験者は, このアニメーション を目視しながらマウスを左右に動かすことにより結合倒立振子モ デルの台車の目標位置を入力する. ただし, スクリーンには, 被験 者が入力した目標位置は表示されない.

本研究では, Fig.2 の測定システムを 2 組用いて, 被験者 4 名が 同時に測定を行えるようにした. 䙲験者がマウスとスクリーンの接 続を変更することにより任意の被験者の組で測定を行うことがで きる.これにより，相手が明らかでない状况で操作を行わせること ができる. 被験者間には, 他被験者の操作の様子がわからないよう についたてを設置する. また，操作音等の雑音に気を取られないよ うにするために被験者にはへッドホンを装着させる.

\section{3. ヒトによる協調バランス正动の測定と部価}

\section{1 測定方法}

協調バランス運動の測定は, 健康な20歳男性8名を被験者とした. 測定は4人1組で行い，同一組の被験者同士の組み合わせ全てにおい

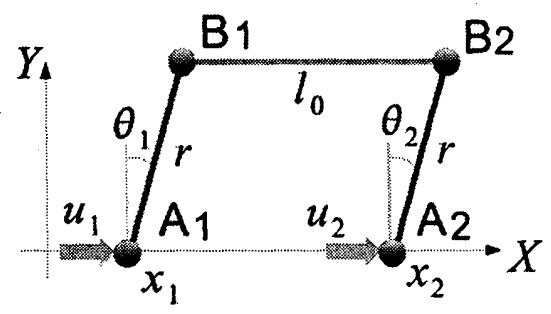

Fig. 1 Coupled inverted pendulum model of competition and cooperation.

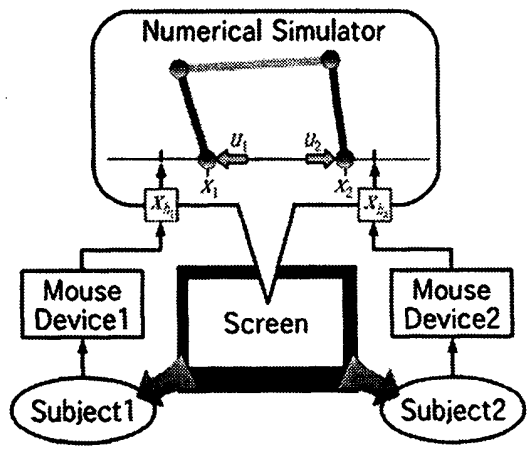

Fig. 2 Measurement system of coupled human balancing tasks.

て測定を行った，実験中は他の被験者との会話を禁止した.

1回の測定の手順を示す．被験者はスクリーンに表示されている 結合倒立振子モデルを,倒さずに20秒以上連続して操作できるよう に任意の回数練習を行う. スタートの合図で被験者は操作を開始し, 相手と協力してバランスを保つ. 20秒を1回の操作とし, 5 回連続で 操作を行う. その後, 被験者が操作する台車を左右入れ替えてさら に5回連続で操作を行う．20秒以内に片方の台車が画面からはみ出 たり，床面に倒れたりした場合は，その回の操作をやり直す。

\section{2 物理㝵の算出}

測定結果より，被験者の操作を表す物理量を算出する. 本研究で は, 台車に関して平均位置, 平均振幅, 最大振幅, 平均速さ, 最大 速さ, 2 台の台車間隔の平均值を用いる. 振子に関しては, 平均角 度, 平均角速度, 2 本の振子の角度差の平均值, バランス誤差の平 均值を用いる.ここで, バランス誤差とは振子の上端と下端の水平 方向の相対変位のことである. 
Table 1 Adjective pairs which evaluates the performance of manipulation of both his own self and the partner.

\begin{tabular}{|c|c|c|}
\hline 1 & よい- & 一 よくない \\
\hline 2 & 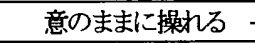 & 一 意のままに操扎ない \\
\hline 3 & 集中できる & － 集中できない \\
\hline 4 & 㗨張感のある & 一 繄張感のない \\
\hline 5 & 慎重な & 一 慎重でない \\
\hline 6 & 協調的な & 一 協調的でない \\
\hline 7 & いいかげんな & ー いいかげんでない \\
\hline 8 & 調和のとれた & 一 調和のとれない \\
\hline 9 & 下手である & 一 下手でない \\
\hline 10 & ふざけている & ー ふざけていない \\
\hline 11 & 敏感な & 一 敏感でない \\
\hline 12 & 攻撃的な & 一攻撃的でない \\
\hline 13 & コントロール性のある & 一 コントロール性のない \\
\hline 14 & 飽きる & 一 飽きない \\
\hline
\end{tabular}

\subsection{SD 法による評価}

測定終了後, 自分の操作および相手の操作についての評価を行う. 感覚のようなあいまいなシステムを評価する場合, 言語を媒介とす る手法が用いられることが多い(2).そのため, 本研究においても言 語を媒介とした測定方法を用いる. 本研究では, 言葉と感覚の関係 を論じるために心理学的な研究でよく用いられる Semantic Differential（SD）法 を用いる.これは，まず評価対象に対して， 意味的に対になる形容語対を評価対象に対する「尺度」として複数 個用意する. 次に，それを何段階かに分割し，被験者は評価対象か ら受ける感覚がその形容語対間のどこに位置するかを選択すると いう手法である.

本研究では, 形容語対に「よい-よくないりのうな否定語との 対を用い, 左側の形容語を評定值1, 右側の形容語を評定値7とする. また, 自分および相手の評価には同一の形容語対を用いる. Table 1 に自分および相手の操作の評価に用いる形容語対を示す.

\section{4 相関分析}

協調バランス運動の測定より得られた物理量と，自分および相手 を評価する形容語対との関係性を調べるために相関分析を行う。

\section{4. 結果}

Table 2に測定結果より算出した物理量とSD法による評価の相関 分析結果より得られた相関係数を示す. 本報では, 台車の平均振幅, 最大速さ, バランス誤差と自分に関する形容語対の相関係数を掲載 する. 表 3 の相関係数のうち, 相関係数の絶対值が高い形容語対を 大きい方から 3 つ太字で示してある. ただし, 相関係数の絶対值が 0.300 以上のものとした.

Table 2より，台車の平均振幅は，1．よい-よくない，11．敏感 な - 敏感でないと共に正の相関があり，9. 下手である-下手でな いと負の相関がある.1.よい-よくないは自分および相手の操作 が良いかどうかを表す形容語対であり，操作の良し悪しを表すと考 えられる. 11. 敏感な - 敏感でないはお互いの操作に敏感に反心し ているかを表す形容語対であり, 被験者の敏感性を表すと考えられ る. また，9. 下手である-下手でないは操作の上手さを表す形容 語対であり，操作の良し悪しを表すと考えられる.

以上より, 台車の平均振幅は操作の良し悪しと被験者の敏感性を 表している.これは, 台車の平均振幅が小さいと操作が上手であり, 被験者は敏感であることを示す。

台車の最大速さは，9．下手である-下手でないと正の相関があ ク，7.、いか代んなーいかかげんでないと負の相関がある. 9. 下 手である一下手でないは操作の上手さを表す形容語対であり，操作 の良し悪しを表すと考えられる. また，7.いいかげんなーいいか げんでないは操作がいいかげんかどうかを表す形容語対であり，操 作の慎重さを表すと考えられる.
Table 2 Result of correlation analysis of sense and human manipulation.

\begin{tabular}{|c|c|c|c|c|}
\hline & \multirow{2}{*}{$\begin{array}{c}\text { 自分に関する } \\
\text { 形容語愔 }\end{array}$} & \multicolumn{3}{|c|}{ 相関係数 } \\
\hline & & $\begin{array}{c}\text { 台車の } \\
\text { 平均振幅 }\end{array}$ & $\begin{array}{c}\text { 台車の } \\
\text { 最大速さ }\end{array}$ & $\begin{array}{c}\text { バランス } \\
\text { 誤差の平均 }\end{array}$ \\
\hline 1 & よい & 0.4017 & -0.1537 & -0.0580 \\
\hline 2 & 意のままに操れる & 0.0736 & -0.1584 & -0.3458 \\
\hline 3 & 集中できる & 0.1531 & 0.0047 & -0.0897 \\
\hline 4 & 緊張感のある & 0.0235 & 0.1702 & 0.1836 \\
\hline 5 & 慎重な & -0.0331 & 0.1545 & 0.3340 \\
\hline 6 & 協調的な & 0.0041 & 0.1713 & 0.3695 \\
\hline 7 & いいかげんな & -0.0911 & -0.4453 & -0.5580 \\
\hline 8 & 調和のとれた & 0.2927 & 0.0071 & 0.2542 \\
\hline 9 & 下手である & -0.4070 & 0.5003 & -0.0330 \\
\hline 10 & ふざけている & 0.0708 & -0.2561 & -0.3700 \\
\hline 11 & 敏感な & 0.5953 & 0.2199 & -0.0455 \\
\hline 12 & 攻慗的な & 0.0754 & -0.0615 & -0.3584 \\
\hline & コントロール珄のある & 0.0411 & -0.1844 & -0.1865 \\
\hline 14 & 飽きる & -0.2024 & 0.0139 & -0.2838 \\
\hline
\end{tabular}

以上より, 台車の最大速さは操作の良し悪しと被験者の慎重さを 表している.これは，台車の最大速度が大きいと操作が上手である が慎重ではないことを示す。

バランス誤差の平均は, 6. 協調的な - 協調的でないと低い正の 相関があり，7. いいかげんなーいいかげんでないと負の相関があ り, 10. ふざけている-ふざけていないと低い負の相関がある. 6. 協調的な-協調的でないは 2 人の被験者が協調して操作を行って いるか脿す形容語対であり, 被験者の協調性を表すと考えられる. 7.いいかげんなーいいかげんでないは操作がいいかげんかどうか を表す形容語対であり, 操作の慎重さを表すと考えられる. また, 10. ふざけている-ふざけていないはまじめに操作を行っているか を表す形容語対であり，これも操作の慎重さを表すと考えられる.

以上より, バランス誤差の平均は操作の協調性と慎重さを表して いる. これは, バランス誤差の平均值が大きいと協調性が低く慎重 でないことを示す。

\section{5. まとめ}

競合と協調を表寸結合倒立振子モデルを用いて，ヒトの操作とヒ トの感性との関連を一部明らかにした. まず, 結合倒立振子モデル を用いて実際にヒトが操作可能な協調バランス運動測定システム を開発した. この測定システムを用いた測定実験を行い,さらにそ の被験者らを対象に，SD 法によって自他のバランス運動に対する 官能評価を行った.

得られた物理量および自他の操作に関する評定值に対して相関 分析を行った結果, 物理量とヒトの感性との間に以下に示す関係性 を見出すことができた.

- 台車の平均振幅と操作の良し悪し, 被験者の敏感性

- 台車の最大速さと操作の良し悪し, 被験者の慎重さ

・ バランス誤差の平均と被験者の協調性, 慎重さ

今後の課題として, 本報の被験者の片方をロボット, すなわちヒ 卜を模した制御器に置きかえる実験を行い, 本報で明らかになった 官能量と物理量との関係をより詳細に検討していく.

\section{考文献}

(1) 日下田淳, 吉田勝俊, 渡辺信一, 中塚亜樹, 結合倒立振子の協調 コントロールタスクにおける感性評価, 日本感性工学会論文誌 Vol.11, No.2, (2012), pp.309-314.

（2）渡辺信一, 尾崎功一, 山崎友麻, 山本純雄, 触感覚による粒子群 の認識と言語評価, 精密工学会誌論文集, 第71巻, 第 11 号, (2005), pp.1421-1425. 